\title{
SPIS RZECZY PODAROWANYCH KOŚCIOLOWI I KLASZTOROWI NORBERTANEK W IMBRAMOWICACH W LATACH 1712-1742
}

W Archiwum Norbertanek w Imbramowicach wśród wielu ważnych dokumentów znajduje się Rejestr rzeczy darowanych różnych dobrodziejów kościołowi naszemu po zgorzeniu kościoła naszego spisany w roku 1712 dnia 1 sierpnia ${ }^{1}$. Sporządzony został przypuszczalnie na polecenie ksieni Zofii Grothówny, która klasztorem zarządzała przez prawie czterdzieści lat. Wybrana na tę funkcję dnia 4 sierpnia 1703 roku, pozostawała na urzędzie do swej śmierci, która nastąpiła 31 maja $1741 \mathrm{roku}^{2}$. Rejestr rzeczy darowanych spisywać zaczęto dnia 1 sierpnia 1712 roku, prawie w całości uzupełniany był za życia Zofii Grothówny. Zaledwie jedna, ostatnia notatka wpisana została dnia 23 kwietnia 1742 r., czyli już za rządów ksieni Katarzyny Bąkowskiej i dotyczy przekazanego przez nią klasztorowi ornatu ${ }^{3}$.

W kontekście wielu zdarzeń, które dla klasztoru imbramowickiego miały znaczenie fundamentalne, rejestr rzeczy darowanych wraz z kroniką klasztorną sióstr norbertanek w Imbramowicach 1703-1741 stanowi dokument niezwykle istotny ${ }^{4}$.

* Beata Skrzydlewska - dr historii sztuki, e-mail: bskrzydlewska@o2.pl

${ }^{1}$ Archiwum Norbertanek w Imbramowicach (dalej: ANI), Rejestr rzeczy darowanych od różnych dobrodziejów kościołowi naszemu po zgorzeniu kościoła naszego spisany w roku 1712 dnia 1 sierpnia, w: Spis rzeczy ofiarowanych do kościola Norbertanek $w$ Imbramowicach.

${ }^{2}$ Zofia Grothówna została obleczona w habit zakonny dnia 10 czerwca 1691 r., śluby zakonne złożyła 12 sierpnia 1694 r. Dnia 4 sierpnia 1703 r. obrana została ksienią klasztoru, funkcję tę pełniła do swej śmierci - 31 maja 1741 r., zob. ANI, Księga Profesji. Katalog sióstr zmartych od r. $p$. 1555 Klasztoru ss. Norbertanek w Imbramowicach pow. Olkuskiego, s. 32.

${ }^{3}$ Katarzyna Bąkowska przybrała habit zakonny dnia 18 maja 1723 r., z rąk biskupa krakowskiego Konstantego Szaniawskiego, śluby wieczyste złożyła dnia 9 kwietnia 1725 r., zmarła dnia 2 maja 1758 r., zob. Księga Profesji. Katalog sióstr, s. 37-38.

${ }^{4}$ Kronika znajduje się w Archiwum Norbertanek w Imbramowicach, ANI sygn. 27, Historya domowa klasztoru imbramowskiego Zakonu Premonstrateńskiego odemnie Zofii Grothowny xieni ręka wtasna pisana, i sobie dla pamięci y sukcessorkom dla informacyi dalszey zostawiona, a w roku Pańskim 1703 zaczęta, Imbramowice, 1703-1741; zob. także Zofia Grothówna, Kronika klasztorna sióstr norbertanek w Imbramowicach 1703-1741, wyd. W. Bielak, W. Żurek, Kielce 2011. 
W wielkim pożarze, który wybuchł 10 lipca 1710 r., zniszczony został doszczętnie kościół i część zabudowań klasztornych, spłonęła także większość mienia ruchomego. Odbudowę rozpoczęto jeszcze w 1710 roku. Odrestaurowano wówczas stare budynki drewniane, dom dla księży, a także ukończono na budynkach klasztornych drewnianą konstrukcję dachu, który przykryto słomą ${ }^{5}$. W kronice klasztornej pod datą 1 lutego $1711 \mathrm{r}$. jest wzmianka o zatrudnieniu słynnego architekta Kacpra Bażanki do projektowania kościoła ${ }^{6}$.

Jednak oprócz przeprowadzania prac budowlanych, konieczne było uzupełnienie braków $\mathrm{w}$ dobytku ruchomym a na to niejednokrotnie nie starczało już funduszy ${ }^{7}$. Nie wystarczało sprzętów przydatnych do życia codziennego a także wyposażenia do urządzenia świątyni. Przede wszystkim, brakowało aparatów kościelnych koniecznych do celów liturgicznych. Znalazło się wielu darczyńców, którzy wspierali klasztor imbramowicki w tych trudnych chwilach. Wśród donatorów były zarówno osoby duchowne jak i świeckie. Najbardziej obdarowała zgromadzenie sama ksieni - Zofia Grothówna, wiele cennych rzeczy przekazal także ksiądz Dominik Lochman.

Jak wynika z rejestru przekazywali klasztorowi różnorakie obiekty zaprzyjaźnieni z klasztorem księża kanonicy krakowscy: Stanisław Kręski, Jan Łuczkiewicz, Suchorski, Andrzej Węgrzynowicz, Marcin Węgrzynowicz. Pamiętał o klasztorze bp Kazimierz Łubieński, a przede wszystkim wielki wspomożyciel klasztoru ksiądz Dominik Lochman ${ }^{8}$.

Dary przekazywały siostry zakonne zamieszkujące klasztor: Anna Kochanowska, Teresa Maierówna, Teresa Miroszewska, Anna Postupalska, Teresa Sobańska, Helena Słomińska, Teresa Wietrzyska, Teresa Zagrodzka, Magdalena Zaleska, także ksieni Zofia Grothówna i Katarzyna Bąkowska.

Wspierały klasztor osoby świeckie zaprzyjaźnione z norbertankami: Konstancja Grothowa - miecznikowa krakowska, Mateusz z Przyłęka Groth - łowczy sandomierski, Mikołaj Grozmaier, Teresa Jordanówna - wojewodzianka bracławska, Anna Komes - burgrabina krakowska, Anna Kostecka - rybaczka krakowska, Agnieszka Lewikowska, Teresa Łubieńska - podstolina koronna, Anna Małachowska - wojewodzina poznańska, Salomea Ponińska, Ewa Szembeka - podkomorzyna krakowska.

Dwukrotnie naczynia liturgiczne przekazały osoby wykupujące się z poddaństwa. Kupowano też aparaty kościelne z pieniędzy wspólnoty klasztornej.

Informacje o obiektach napływających wówczas do kościoła i opactwa odnajdujemy także w kronice klasztornej, w której spisywane są różnorodne wydarzenia ważne dla klasztoru. Wiadomości o darowiznach, choć rzetelnie wprowadzane

${ }^{5}$ Grothówna, Kronika klasztorna, s. 47.

${ }^{6}$ Tamże, s. 48.

${ }^{7}$ B. Skrzydlewska, Zakon norbertanek $w$ Imbramowicach i jego działalność na rzecz ochrony dóbr kultury w latach 1703-1999, w: Twórcy i dzieła. Studia z dziejów kultury artystycznej, red. M. Kitowska-Łysiak, L. Lameński, I. Rolska-Boruch, Lublin 2007, s. 131-146.

${ }^{8}$ Informacje dotyczące darczyńców zamieszczone zostały w przypisach odnoszących się bezpośrednio do Rejestru. 
przez kronikarki, gubią się w gąszczu innych informacji ${ }^{9}$. W rejestrze informacje dotyczące darowizn spisane są w sposób bardzo klarowny. Można dowiedzieć się, jakie przedmioty przekazywano klasztorowi, a także uzyskać wiedzę, kim byli poszczególni ofiarodawcy.

Rejestr rzeczy darowanych od różnych dobrodziejów kościołowi naszemu po zgorzeniu kościoła naszego spisany w roku 1712 dnia 1 sierpnia jest jednym z dokumentów umieszczonych w Spisie rzeczy ofiarowanych do kościoła Norbertanek $w$ Imbramowicach ${ }^{10}$.

W rejestrze informacje ułożone są według czasu ich przekazania klasztorowi. Wyszczególnione obiekty opatrzone są krótkim opisem z uwzględnieniem materiału, z którego zostały wykonane. Podano imiona i nazwiska darczyńców.

Przygotowując tekst do druku, zastosowano się do wymogów Instrukcji wydawniczej dla źródet historycznych od XVI do polowy XIX wieku ${ }^{11}$.

Zachowano charakter potoczny języka, pozostawiając błędy językowe. Bez zmian pozostawiono także pisownię nazwisk, nawet, jeśli występowały różnice w pisowni tego samego nazwiska. Rozwinięto skróty imć - Jegomość; J. Mość - Jejmość; J.W. - Jaśnie Wielmożny, S.- św. W nawiasie kwadratowym wprowadzono: rozwinięcie skrótów, a także z lewej strony tekstu (czasem w tekście) paginację, z prawej zaś strony wpisany jest wytłuszczoną czcionką rok wpisu do Rejestru.

Wiadomości odnoszące się do sióstr imbramowickich podawane są w przypisach, na podstawie Księga Profesji. Katalog sióstr zmartych od r. p. 1555 Klasztoru ss. Norbertanek w Imbramowicach pow. Olkuskiego ${ }^{12}$.

W tekście znajduje się duża ilość terminów z zakresu włókiennictwa, które dzisiejszemu czytelnikowi mogą nastręczać wiele trudności. Podany termin objaśniony został $\mathrm{w}$ przypisie tylko jeden raz, jeśli pojawia się on w tekście $\mathrm{w}$ innych miejscach nie wprowadzano już odnośników.

Definicję nieużywanych współcześnie pojęć przytaczano na podstawie wydanego przez Bibliotekę Muzealnictwa i Ochrony zabytków, Stownika terminologicznego włókiennictwa, autorstwa Marty Michałowskiej ${ }^{13}$.

${ }^{9}$ Zofia Grothówna, Kronika klasztorna.

${ }^{10}$ Oprócz Rejestru w Spisie rzeczy ofiarowanych... znajdują się ponadto Rejestr Generalny wszystkich rzeczy kościelnych spisanych roku Pańskiego 1781, Rejestr wszystkich rzeczy kościelnych spisanych w roku 1862 dnia 25 października, a także Rejestr opisany wszystkich aparatów, srebra i relikwii, które znajduja się przy kościele naszym imbramowskim po śmierci świętej pamięci Matki naszej Dobrodziejki Jej Mości Panny Zofii Grothówny, ksieni imbramowski, dnia 26 czerwca Roku Pańskiego 1741. Zob. Spis rzeczy ofiarowanych do kościoła Norbertanek w Imbramowicach,.

${ }^{11}$ Kazimierz Lepszy, Instrukcja wydawnicza dla źródet historycznych od XVI do połowy XIX wieku, Wrocław 1953.

${ }^{12}$ Księga Profesji. Katalog sióstr.

${ }^{13}$ M. Michałowska, Stownik terminologiczny wtókiennictwa, Warszawa 1995. 
[s. 3]

In Nomine Domini

\section{Rejestr rzeczy darowanych od różnych dobrodziejów kościołowi naszemu po zgorzeniu kościoła naszego spisany w roku 1712 dnia 1 sierpnia}

\section{[1 VIII 1712]}

Od Jegomości księdza Suchorskiego kapa czarna aksamitna z galonem jedwabnym pomarańczowym i frędzlą wokoło szczytu [a] podszyta płótnem obłóczystym $^{14}$.

Od tegoż ornatów trzy lino fiałkowy ${ }^{15}$ atłasowy, kolumna aksamitna, galony szychowe ${ }^{16}$ podszyty płótnem obłóczystym.

Drugi zielony, atłasowy ceglasta kolumna biało wzorzysta galony i frędzla u niego obłóczysta jedwabna podszyty, płótnem czerwonym. Trzeci cytrynowy, wzorzysty, kolumna ceglasta wzorzysta, galony i frędzla pstra, jedwabna, podszyty płótnem cytrynowym.

Do tych ornatów pasów włóczkowych z niciami 3. Od tegoż spódnica zielona w pasy, bogato złocista.

\section{[1713]}

Roku 1713 dnia 10 lutego

Od Wielmożnego Jegomości księdza Marcina Węgrzynowicza k[anonika]. krakowskiego ${ }^{17}$ ornat fiałkowy atłasowy [s. 4] kolumna takaż aksamitna, potrzeby szychowe, podszywka obłóczysta płócienna od tego ornata palka welum bursa takaż.

\section{[1714]}

Roku 1714 dnia 1 maja

Od Jaśnie Wielmożnego Książęca Jegomości księdza Kazimierza Łubieńskiego ${ }^{18}$,

${ }^{\mathrm{a}}$ Wyraz nieczytelny

${ }^{14}$ Obłóczysty - wsp.ółcześnie „lejący”, ciężki.

${ }^{15}$ Kolor fiałkowy (od fiołek) - fioletowy z zimnym odcieniem; Terminy dotyczące włókiennictwa objaśniane są na podstawie Stownika Terminologicznego Włókiennictwa, zob. Marta Michałowska, Słownik Terminologiczny Włókiennictwa, Seria B, t. XCII, Warszawa 1995.

${ }^{16}$ Szych - przędza lniana lub bawełniana, okręcana spiralnie paseczkiem miedzianym posrebrzanym lub pozłacanym. Stosowany od co najmniej od XVI do XIX w. do wyrobu tanich pasamonów i koronek metalowych.

${ }^{17}$ Marcin Węgrzynowicz (ur. ? - zm. 25 IV 1717 r.), ksiądz, kanonik krakowski, kustosz kielecki, archidiakon pilicki, proboszcz w Tczycy, zob., J. Wiśniewski, Katalog prałatów i kanoników sandomierskich od 1186 do 1926 r. Tudzież sesje kapituty sandomierskiej do 1581 do 1866 r., Radom 1928, s. 305.

${ }^{18}$ Kazimierz Łubieński (ur. 1652 r. - zm. 1719 r. w Kielcach). Studiował w Akademii Krakowskiej i w Kolegium jezuickim w Rzymie. Sakrę biskupią otrzymał dnia 6 lipca 1701 r. na Jasnej Górze. W latach 1700-1701 i 1702-1710, pełnił funkcję administratora biskupstwa krakowskiego. W latach 1705-1710 biskup chełmski, od dnia 10 kwietnia 1710 roku został biskupem krakowskim. W 1711 r. zwołał diecezjalny synod reformistyczny, zob. B. Kumor, Dzieje diecezji krakowskiej do roku 1795, t. 2, Kraków 2002, s. 525-526. 
biskupa krakowskiego dobrodzieja naszego ornatów ośm, dwa białe adamaszkowe z galonami i złotem i kitajką ${ }^{19}$ białą podszyte: dwa czerwone adamaszkowe z galonami złotemi, takąż kitajką podszyte, dwa zielone adamaszkowe z galonami złotemi takąż kitajką podszyte. Dwa fiałkowe adamaszkowe z galonami złotemi takąż kitajką podszyte. Do tych wszystkich stuły, manipularze, wela, bursy i palki takijże materii ze złotemi galonami.

Roku tegoż dnia 20 lipca

Od Wielmożnej Jegomości Pani Konstancji Grothowej, miecznikowej krakowskiej ornatów dwa białych, jeden z pomarańczową lamową kolumną, galon złoty, kitajką białą podszyty. Welum, bursa, palka, stuła, manipularz takiż materii; drugi z pąsową aksamitną kolumną, podszyty bagazją ${ }^{20}$ pomarańczową z weneckim galonem.

\section{[1715]}

Roku 1715 dnia 20 marca

Od Wielmożnego Jegomości księdza komisarza Dobrodzieja naszego po zmarłym Jegomości Panu Grabiańskim ornatów dwa. Jeden ceglasty złocisty, potrzeby ${ }^{21}$ [s. 5] srebrne, takąż kitajką podszyty; drugi jasno obłoczysty, morwowy $\mathrm{z}$ koronką marcepanową ${ }^{22}$, podszyty kitajką takąż.

Roku tegoż dnia 15 maja

Dobrodzika nasza Jejmość Panna Ksieni Zofia Grothówna, sprawiła swoim kosztem ornat aksamitny czarny i dalmatyki takież ze stułami, manipularzami. Welum, bursa i palka takaż, a to wszystko z galonami złotemi podszyte kitajką pomarańczową.

\section{[1716]}

Roku 1716 Dnia 15 sierpnia

Od Wielmożnego Jegomości księdza Marcina Węgrzynowicza kanonika krakowskiego, ornat koloru izabelowego ${ }^{23}$. Kwiat po nim kręcony, złoty galon wenecki złoty, płótnem obłóczystym podszyty ze stułą i manipularzem.

\section{[1717]}

Roku 1717 dnia 12 sierpnia

Dobrodzika nasza, Jejmość Panna Ksieni Zofia Grothówna, sprawiła swoim kosz-

${ }^{19}$ Kitajka - cienka, dość gęsta, gładka tkanina jedwabna o splocie płóciennym, cieńsza i zwykle gorsza gatunkowo od tafty. Wyrabiana na Wschodzie, sprowadzana do Polski w XVII w, wytwarzana też w Grodnie za czasów Stanisława Augusta Poniatowskiego.

${ }^{20}$ Bagazja, bagazya - 1. rzadka, lekka tkanina bawełniana o splocie płóciennym, barwiona na różne kolory. Wytwarzana na Wschodzie i Zachodzie (gł. we Francji i Włoszech) do XVII w., importowana do Polski; 2. wzorzysta tkanina w „karpia łuskę” lub kwiaty, albo drukowana tkanina bawełniana, względnie tania. Używana w Polsce w XVIII w. na suknie, kamizelki, chustki, rzadziej jako dekoracyjna.

${ }^{21}$ Potrzeby - wyszycia taśmowe ze sznurków pasamoniczych, z odpowiednimi guzami itp. dodatkami.

${ }^{22}$ Marcepanowy - biały o chłodnym odcieniu szklanym.

${ }^{23}$ Kolor izabelowy - niezdecydowany brudnożółty. 
tem te rzeczy do kościoła naprzód. Alb sześć z koronami, humerałów dwanaście z koronkami, z osobna z szerokiemi koronami, humerał jeden białym szyciem szyty, korporałów z koronkami ośm, puryfiaktorów z koronkami dwanaście. Ręczników z białym szyciem dziesięć, komży z koronami trzy, rokieta jedna, pasów jedwabnych dwa, jeden karmazynowy drugi obłoczysty.

Srebro także od niej dane. Kielich srebrny pozłocisty, wszystek z patyną. Takaż puszka na olej Święty, srebrna w środku, pozłocista z wieczkiem. Relikwiarz srebrny z relikwiami dwunastu Apostołów S.S. w środku Drzewo Krzyża Świętego. Krucyfiks mały, srebrny z relikwią św. Piusa w piedestale.

[s. 6]

[1718]

Roku 1718 dnia 10 czerwca

Oddał Jegomość ksiądz Andrzej Węgrzynowicz ${ }^{24}$ kanonik krakowski, po zmarłym JMCi Marcinie Węgrzynowiczu, rodzonym swoim, z zaznaczeniem dyspozycji jego, ornat czerwony $\left[^{b}\right]$ kolumna na atłasie biała złotem i srebrem haftowana i jedwabiami różnemi, potrzeby weneckie, podszyty płótnem obłóczystym. Do tegoż ornata welum, bursa, stuła, manipularz, palka z takiż materii. Alba niesokurowa $\mathrm{z}$ koronami niesokurowemi ${ }^{25}$. Welum na atłasie perłowym szyte, bursa palka i korporał złotem szyty, poduszka zielona sukienna pod księgi.

Roku 1718 dnia 1 sierpnia

Dobrodzika nasza Jejmość Panna ksieni Zofia Grothówna sprawiła do ołtarza św. Kajetana antependią białą adamaszkową ze złotemi galonami i z frędzlą. Obrusów dwa cienkich z koronami. Lichtarzów sześć cynowych i sukno zielone na gradusy. Ręczników dwa z koronami takimiż jak u obrusa.

Roku tegoż dnia 23 sierpnia

Od Wielmożnego Jegomości księdza Dominika Lochmana ${ }^{26}$ kanonika i archiprezbitera krakowskiego, komisarza i Dobrodzieja naszego poduszek aksamitnych pąsowych z galonami szychowemi sześć, od tegoż obrusów prostego płótna lnianego sześć, krucyfiks odlewany srebrny na czarnym krzyżu drewnianym. [s. 7]

Roku tegoż dnia 3 października

Od Jaśnie Wielmożnej Jejmości Pani Anny Małachowskiej²7, wojewodziny po-

${ }^{\mathrm{b}}$ Wyraz nieczytelny.

${ }^{24}$ Andrzej Węgrzynowicz (ur. ? - zm. w 1727 r.), ksiądz, doktor obojga praw, kanonik krakowski, kielecki, proboszcz w Imbramowicach.Wiśniewski, Katalog, s. 305.

${ }^{25}$ Niesokor, niesokur (staropolskie) - określenie surowego jedwabiu, z którego pleciono pasy i wyrabiano koronki.

${ }^{26}$ Ks. Dominik Lochman (1644-1742), m.in. kanonik krakowski, archiprezbiter mariacki w Krakowie (1700-1710), doktor obojga praw wielce zasłużony dla klasztoru imbramowickiego. Duża liczba zachowanych w klasztorze. starodruków i dzieł sztuki posiada jego proweniencję, zob. Grothówna, Kronika klasztorna, s. 2.

${ }^{27}$ Anna Konstancja Małachowska, wojewodzina poznańska, druga żona Stanisława Małachowskiego, siostra Jerzego Aleksandra Lubomirskiego, zob. S. Uruski, Rodzina. Herbarz szlachty polskiej, t. 1-14, Warszawa, t. 9, s. 181; t. 10, s. 174. 
znańskiej kielich srebrny pozłocisty, gładki z patyną.

Roku tegoż dnia 1 listopada

Od Jejmości, Pani Agnieszki Lewikowskiej, spódnica ceglasta, złoty kwiatek i jedwabny poniej z koronką srebrną.

Roku tegoż dnia 7 listopada

Od Wielmożnej Jejmości Pani Ewy Szembekowej, wojskiej oświęcimskiej28, spódnica perłowa w pasy i kwiatki złote z koronką marcepanową ${ }^{29}$.

Roku tegoż dnia 10 listopada

Od Jaśnie Wielmożnej Jejmości Pani Teresy Łubieńskiej, podstoliny koronnej, materii różowej w pasy ze srebrem łokci półszósta.

Roku tegoż dnia 10 grudnia

Od Pani Anny Kosteckiej, rybaczki krakowskiej, spódnica zielona w pasy z koronką marcepnową.

Roku tegoż dnia 10 lipca

Dobrodzika nasza Jejmość Panna ksienia Zofia Grothówna dała mszał zakonny oprawny [s. 8] w. aksamit karmazynowy ze srebrem, i tę antepedią białą adamaszkową z galonami złotemi i frędzlą do ołtarza św. O. Norberta. Obrusów dwa cienkich z koronami, ręczników dwa także z koronami, welum białe, adamaszkowe z bursą i palką, podszyte kitajką karmazynową a z kampanką złotą ${ }^{30}$.

Także do S. Józefa ołtarza, obrusów dwa z koronami, ręczników trzy.

Roku tegoż dnia 10 sierpnia

Siostra Teresa Maierówna ${ }^{31}$, która od różnych Dobrodziejów wypraszając, sprawiła andepedią adamaszkową białą ze złotemi galonami i z frendzlą do ołtarza św. Józefa.

Roku tegoż dnia 16 sierpnia

Siostra Anna Postupalska ${ }^{32}$ sprawiła albę z cienkiego płótna z koronkami klockowemi.

Roku tegoż dnia 6 września

Siostra Helena Słomińska ${ }^{33}$ sprawiła korporał złotem szyty.

${ }^{28}$ Ewa Apolonia z Nielepców Szembekowa, żona Antoniego Felicjana Szembeka ze Słupowa, zob. Niesiecki, Herbarz, t. 8, s. 616.

${ }^{29}$ Marcepanowy - biały o chłodnym odcieniu.

${ }^{30}$ Kampanka, kampana, kompana - rodzaj wąskiej koronki klockowej. Wytwarzana we Francji w XVII - pocz. XVIII w., w Polsce w XVIII w.

${ }^{31}$ Teresa Maierówna, habit przyjęła w lipcu 1691 r., śluby wieczyste złożyła w 1692 r. zmarła dnia 6 października 1765, zob. Księga Profesji, s. 32.

${ }^{32}$ Anna Postupalska, przyjęła habit 26 lipca 1707 r., profesję złożyła w 1707 r., zm. 11 maja 1741 r., Tamże, s. 34-25.

${ }^{33}$ Agnieszka Helena Słomińska, przyjęła habit dnia 30 X 1678 r., złożyła profesję w 1709 r., zmarła 10 marca 1743, zob. tamże, s. 24. 


\section{[1720]}

Roku 1720 dnia 29 stycznia

Od Jaśnie Wielmożnej Jejmości Panny Teresy Jordanówny, wojewodzianki bracławskiej, antepedium ceglaste z wstęgą złotą do ołtarza św. O. Norberta i z koronami białymi opięte.

dnia 5 marca

Od Dobrodziki naszej Jejmości Panny Zofii Grothówny [s. 9] Ksieni, patena wielka srebrna pozłocista do komunii św. Antypedyjki dwie do małych ołtarzyków z obruskami, z marcepanową koronką. Obrus do N.P.M. z koronkami sztuczkowego płótna, ręczników rąbkowych ${ }^{34}$ cienkich z koronkami16. Korporałów cztery z koronkami, komżą rąbkową z koronami klockowemi.

dnia 10 sierpnia

Ze spólności kupiono sztukę płótna do kościoła, z którego ukroiło się obrusów 4 na ołtarze, komży dwie, humerałów 5, puryfikaterzy 18.

dnia 14 października

Od siostry Anny Kochanowskiej ${ }^{35}$ ornat czarny aksamitny z galonami srebrnymi $\mathrm{z}$ manipularzem i stułą.

dnia 24 grudnia

Od Wielmożnego Jegomości księdza Dominika Lochmana, kanonika i archiprezbitra krakowskiego, komisarza i dobrodzieja naszego przykrycie na wszystkie ołtarze w pasy z frędzelkami.

\section{[1721]}

Roku Pańskiego 1721 dnia 12 lutego

Dalmatyki adamaszkowe, karmazynowe, sporządziły się z kołdry po ś.p. Jegomości Panu Myszkowskim.

[s. 10]

dnia 20 maja

Dały się zrobić dalmatyki białe, złociste z suknie od Jaśnie Wielmożnej Jejmości

Ewy Szembekowej, podkomorzyny krakowskiej, potrzeby do nich konwent prowidował.

Item ornat różowy w kwiaty z tej materii co dała Jejmość Pani Teresa Łubieńska ${ }^{36}$, podstolina koronna. Potrzeby u niego srebrne, podszyty kitajką ' białą, na które konwent łożył.

dnia 15 sierpnia

Krucyfiks nasadzany koralami i pasyjka sama koralowa wszystka, od Wielmożne-

c Następują skreślone wyrazy: bladoróżowa.

${ }^{34}$ Rąbek - cienka i rzadka tkanina lniana, prawie przezroczysta. Wyrabiana na Śląsku i w Młopolsce co najmniej od XVI w., w XVIII wieku także drukowana w rozmaite wzory.

${ }^{35}$ Anna Kochanowska, przyjęła habit 29 sierpnia 1719 r., złożyła profesję 11 września 1718 r., zmarła 22 XI 1761 r., Księga Profesji, s. 35-36.

${ }^{36}$ Teresa Łubieńska, podstolina koronna, córka Anny Małachowskiej, wojewodziny poznańskiej, zob. Grothówna, Kronika klasztorna, s. 115. 
go Jegomości księdza Łuczkiewicza ${ }^{37}$ kanonika krakowskiego.

dnia 15 grudnia

Ampułek srebrnych para i miseczka do nich takaż od szewców, którzy się z poddaństwa wykupowali.

\section{[1722]}

Roku Pańskiego 1722, dnia 9 stycznia

Relikwiarz świętego Liberiusza w srebro oprawny od Wielmożnego Jegomości księdza Dominika Lochmana, kanonika krakowskiego, Dobrodzieja naszego. dnia 23 lipca

Relikwiarz srebrny, z relikwią św. Joachima i św. Anny od siostry Anny Postupalskiej dany.

\section{[1723]}

Roku Pańskiego 1723 dnia 19 marca

Od Dobrodziki naszej Jegomości Panny Zofii Grothówny [s. 11] ksieni, monstrancja srebrna pozłocista. Wszystka nasadzana różnemi kamieniami.

Od tejże kapa biała na dnie adamaszkowym białym kwiat wielki kręconego złota, podszyta kitajką blado różową z potrzebami złotemi. Stuła do tejże kapy z takijże materii. Item komża rąbkowa z koronami szerokiemi klockowemi, kutasów par dwie, jedne karmazynowe węzełkowe z prawdziwemi perłami, drugie białe także węzełkowej roboty, Item alba rąbkowa w kwiateczki z koronami takiemiż jako i u komży.

dnia 25 lipca

Siostra Anna Postupalska, która od różnych dobrodziejów wypraszając, sprawiła antepedium adamaszkową białą ze złotymi galonami i frendzlą do ołtarza Anny Świętej.

dnia 14 sierpnia

Dobrodzika nasza Jmość Panna Zofia Grothówna ksieni, sprawiła do ołtarza NPM antepedję adamaszkową białą ze złotemi galonami i frendzlą i przykrycie zielone, złociste $\mathrm{z}$ ręcznikiem z koronami dzierganemi i z kampanką złotą z zielonym.

[s. 12]

Roku Pańskiego 1723 Dnia 21 octobra

Jan Ciempka ${ }^{38}$ sprawił kielich srebrny, w środku pozłocisty z patyną, wykupując się z poddaństwa.

[1724]

Roku Pańskiego 1724 dnia 14 czerwca

${ }^{37}$ Jan Łuczkiewicz - zm. 1725, kanonik kapituły katedralnej na Wawelu, zob. J. Szczepaniak, Spis prepozytów i plebanów diecezji krakowskiej (XVIII w.), Kraków 2008, s. 25.

${ }^{38} \mathrm{~W}$ kronice spisywanej przez Zofie Grothówę, pod tą samą data istnieje następująca informacja: „Oddał do kościoła naszego kielich z pateną w środku pozłocony Jan Ciempka z Przedmieścia krakowskiego, który był obiecał za uwolnienie z poddaństwa”. Grothówna, Kronika klasztorna, s. 362. 
Od Dobrodziki naszej Jegomości Panny Zofii Grothówny, ksieni, piedestalik pod monstrancję zielony, aksamitny z frędzlą złotą, stuła także aksamitna zielona jedna, z szychowym galonem, druga materialna zielona złoty kwiat peoni z takimże galonem. Welum, bursa i palka takaż materialna.

Dnia 15 oktobra

Od Wielmożnego Jegomości księdza Dominika Lochmana, kanonika krakowskiego, dobrodzieja naszego mszał.

[1725]

Roku Pańskiego 1725 dnia 17 sierpnia

Od Wielmożnego Jegomości księdza Lochmana, dobrodzieja naszego, mszałów rekwialnych sześć.

\section{[1726]}

Roku Pańskiego 1726 dnia 20 marca

Od Dobrodziejki naszej Jegomości Panny Zofii Grothówny, ksieni, humerał wielki z koronkami klockowemi, na ćwierć szerokiemi, dla zakonników, gdy się, który z kapturem trafi, także ręczników białym szyciem szytych sześć.

[s. 13]

Roku Pańskiego 1726

Od Wielmożnego Jegomości księdza Lochmana Dobrodzieja naszego, krucyfiks słoniowej kości na czarnym podestale do ołtarza N.P. Maryi.

W tymże Roku

Sprawiła do kościoła naszego siostra Postupalska tuwalnię ${ }^{39}$, na której są wyszyte pomarańcze w zielonościach. Tę tuwalnię ofiarowała na ołtarz św. Anny.

\section{[1727]}

Roku 1727 dnia 4 listopada

Darował do kościoła naszego Wielmożny Jegomość ksiądz Lochman, Dobrodziej nasz, biretów czarnych, sukiennych sześć.

$\mathrm{W}$ temże roku dnia 10 grudnia

Dobrodzika Panna ksieni oddała kościołowi naszemu relikwiarzów dwa, swojem kosztem sprawionych. Jeden z relikwią św. Zachariasza i św. Elżbiety, drugi z relikwią św. Kajetana.

W temże czasie szary trybularz, który był bardzo popalony także i lampka dała się przerobić na nowy trybularz który jest.

Siostra Kochanowska dała antepedii dwie, krzyżową robotą szytych. Jedne do obrazu św. Anny, drugą do św. Józefa, do których niektóre siostry przykładały się. Także poduszek sześć krzyżowa robotą.

[1728]

W roku 1728 dnia 10 maja

${ }^{39} \mathrm{~W}$ znaczeniu liturgicznym może być to określenie naramiennego welonu, pasa tkaniny, który trzymano przed przystępującymi do komunii oraz perisonium. Znane są także tuwalnie żałobne. 
Lichtarzów para srebrnych przybyło do kościoła, które są zrobione z monstrancji starej ażeby małe były, dołożono do nich ze spólności złotych tysiąc.

dnia 24 czerwca

Relikwiarz SS. Patronów polskich wielki, w orła robiony od Wielmożnego Jegomości Dominika Lochmana kanonika katedralnego krakowskiego dobrodzieja naszego.

Tegoż dnia lustry dwie z przyszafnemi lichtarzykami, srebrne, sprawiła Dobrodzika nasza Panna Ksieni swojem kosztem do Wielkiego ołtarza na chwałę Panu Bogu.

Antepedia trzy czarnych z pomarańczowemi galonami i frędzlą tąkoż od siostry Magdaleny Zaleskiej ${ }^{40}$ takich, jakichże antepedii czarnych, adamaszkowych od Jaśnie Wielmożnej Jejmości Panny Teresy Jordanówny ${ }^{41}$, wojewodzianki bracławskiej.

\section{[1729]}

W Roku Pańskim 1729

Sporządziła Dobrodzika Panna Ksieni do kościoła naszego stuł białych partowych $^{42}$ ze starej materii pięć, także czarnych stuł 7, wel 1 czarnej, drugi biały atłaskową robotą, pasów czarnych jedwabnych.

[s. 15]

Roku Pańskiego 1729 dnia 11 stycznia

Miednica z nalewką srebrna pstro złocista od Wielmożnego Jegomości księdza Dominika Lochmana Dobrodzieja naszego.

W tymże roku dnia 20 października

Antchwos cynowy do zakrystii i kufel miedziany pobielany pod antchwos od

Wielmożnego Jegomości księdza Lochmana Dobrodzieja naszego.

W tymże roku dnia 27 października

Welów dwa karmazynowych, bursa jedna, palka z potrzebami ${ }^{43}$ złotemi, kitajką karmazynową podszyte, bogato złociste, od Wielmożnego Jegomości księdza Dominika Lochmana dobrodzieja naszego.

W tymże roku dnia 3 listopada

Alba cienka lnianego płótna z koronkami wąskiemi, klockowemi od Wielmożnej Jejmości Pani Ewy Szembekowej Podkomorzyny krakowskiej.

W tymże roku dnia 3 grudnia

Alba sztuczkowa z obgrubniego płótna z koronkami siatkowemi i dwa humerały, którą Dobrodzika Panna Ksieni dała z płótna, co po śmierci Pana Bartłomieja

${ }^{40}$ Magdalena Zaleska, obleczona w habit 7 sierpnia 1720 r., złożyła profesje 7 sierpnia 1721 r., zmarła 7 maja 1737 r., zob. Księga Profesji, s. 37.

${ }^{41}$ Teresa Jordanówna, wojewodzianka bracławska, następnie żona Aleksandra Łaszewskiego, miecznika wieluńskiego, zob. Uruski, Rodzina, t. 6, s. 98.

${ }^{42}$ Part - gruba tkanina konopna lub lniana z najgrubszych pakuł (odpadki włokna), uzyskiwanych przy klepaniu lnu, zgrzebna, nie bielona.

${ }^{43}$ Potrzeby, wyszycia taśmowe lub sznurkowe z odpowiednimi guzami itp. wytwarzane zwykle przez pasamoników. 
Siemieńskiego ${ }^{44}$ zostało, za duszę Jego.

Dnia tegoż dała Dobrodzika Panna Ksieni komżę rąbkową ${ }^{45}$, którą za wspólne pieniądze sporządziła z koronami dzierganemi z kratą.

Dnia tegoż dała obrus cienki sztuczkowy Dobrodzika Panna ksieni ze swojego płótna do ołtarza św. Anny.

W tymże Roku dnia 4 grudnia ${ }^{\mathrm{d}}$

W tymże Roku dnia 5 grudnia

Obrusek lnianego płótna, dała siostra Teresa Zagrodzka ${ }^{46}$ do kapitularza na ołtarzyk Najświętszej Pannye.

Od siostry Józefy Sobańskiej do zakrystii ręczników drelichowych 4.

[s. 16]

[1730]

Roku Pańskiego 1730

dnia 13 maja

Relikwiarz Drzewa Krzyża Świętego darował Wielmożny Jegomość ksiądz Lochman Dobrodziej nasz, dawał na oprawę jego srebra i na pozostałe dwadzieścia siedem czerwonych złotych, także pierścieni trzy diamentowych dokupiwszy rubinów i czwartego kamienia, do czego się połową srebra przyłożyła Dobrodzika Panna Ksieni nasza Mości Panna Zofia Grothówna.

W tymże roku dnia 19 czerwca

Welów dwa, palek dwie, bursów dwie, bogato złocistych z potrzebami złotemi kitajką białą podszyte darował do kościoła naszego Wielmożny Jegomość ksiądz Dominik Lochman Dobrodziej nasz.

W tymże roku dnia 28 czerwca

Obrusów dwa lnianych jeden na Wielki ołtarz drugi do Najświętszej Panny z listewkami białym szyciem rzezaną robotą dała do kościoła naszego Dobrodzika nasza Mości Panna Zofia Grothówna Ksieni.

[1731]

Roku 1731 dnia 8 czerwca

Dobrodziejka nasza Jejmość Panna Zofia Grothówna ksieni, dała ornat biały, kwiaty złote z jedwabnemi, potrzeby szychowe weneckie, płótnem pomarań-

${ }^{\mathrm{d}}$ Następuje wykreślone zdanie.

${ }^{\mathrm{e}}$ Wykreślone całe zdanie, nieczytelne.

${ }^{44}$ Bartłomiej Siemieńki, prawdopodobnie ekonom w klasztorze, zob. „Chorując przez kilkanaście niedziel na puchlinę, pan Bartłomiej Siemieński, będąc opatrzony św. sakramentami, umarł o godzinie 6 po południu, który wiernie służył klasztorowi naszemu przez 25 lat trzymając organictwo przy kościele, także wszytkie szpiklerze zbóż, pisząc regestra tak dochodów, jak rozchodów po wszystkich folwarkach naszych, który niechaj odpoczywa z Panem Bogiem w niebie na wieki.", zob. Grothówna, Kronika klasztorna, s. 448.

${ }^{45}$ Rąbek - cienka i rzadka, prawie przezroczysta tkanina lniana o splocie płóciennym, gorzej bielona niż batyst. Wyrabiana na Śląsku i w Małopolsce co najmniej od XVI w., w XVIII w. także drukowana w rozmaite wzory.

${ }^{46}$ Teresa Zagrodzka przyjęła habit zakonny dnia 29 sierpnia 1717 r., zob. Ksiega Profesji, s. 35. 
czowym podszyte, które ze spólnych pieniędzy zapłaciła.

Drugi ornat także biały dała do kościoła naszego Dobrodzika Mości Panna ksieni po siostrze Józefie Urbańskiej ${ }^{47}$, na białym dnie floresy złote i kwiaty różowe w zielonościach, które swoim kosztem sprawiła, potrzeby także weneckie, pomarańczowa podszywka.

Ornat trzeci sprawiła swoim kosztem siostra Teresa Maierówna, biała lama, kolumna także lamowa różowa, galony szychowe, płótnem zielonym podszyte.

Do tych wszystkich trzech ornatów nie było welów, burs, palki, stuły i manipularze.

[s. 17]

[1734]

Roku Pańskiego 1734

dnia 23 czerwca

Darował do kościoła naszego Wielmożny Jegomość ksiądz Lochman Dobrodziej nasz obicie burgatelowe ${ }^{48}$ stare, którego jest na trzech sztukach brytów.

[1735]

Roku Pańskiego 1735 dnia 7 sierpnia

Darował do kościoła naszego Wielmożny Jegomość ksiądz Stanisław Kręski ${ }^{49}$, kantor i kanonik krakowski, dobrodziej nasz - ornat aksamitny, czerwony, ze złotemi galonami, białą kitajką podszyty, do którego jednakże są potrzeby ${ }^{50}$, stuła, manipularz, bursa, pala i wel, także ze złotemi galonami.

Dnia tegoż darował Wielebny Jegomość, ksiądz Lochman dobrodziej nasz do kościoła naszego welum białe, lamowe, kitajką białą podszyte.

[1737]

Roku 1737, dnia 7 sierpnia

Dobrodziejka Jejmość Panna ksieni dała obrus cienki z koronkami dzierganemi do ołtarza św. Kajetana.

[1738]

Roku 1738 dnia 20 marca

Wielmożny Jegomość ksiądz Dominik Lochman dobrodziej nasz, darował do kościoła naszego dwie piramidy z relikwiami świętemi różnemi. Od tegoż Jegomości Dobrodzieja naszego darowana w tym roku trumienka z relikwiami, znaczną św. Wiktorii Męczennicy do kościoła.

W tymże roku dnia 2 września dała kościołowi naszemu Jejmość Dobrodziejka Panna ksieni komży cztery, alb dwie, humerałów trzy puryfikaterzy [s.18] dwanaście, komeżek dla chłopców cztery, ręczników dwa, kosztem swoim dała opranie.

47 Józefa Urbańska - zm. 11 kwietnia 1790 r. Wstąpiła do nowicjatu w 1730 r., profesja 1731 r., siostra chórowa, zob. Księga Profesji, s. 39.

${ }^{48}$ Brokatowe

${ }^{49}$ Stanisław Kręski, proboszcz, kanonik kapituły katedralnej na Wawelu, kantor. Zob. Szczepaniak, Spis prałatów, s. 14.

${ }^{50}$ Potrzeby w tym wypadku oznaczają cały komplet ornatowy. 
Relikwie różne Świętych od Wielmożnego Jegomościa księdza Dominika Lochmana Dobrodzieja, darowane relikwiarz srebrny duży. Dobrodzika Jejmość Panna Ksieni do kościoła naszego.

Wielmożny Jegomość ksiądz Lochman dobrodziej nasz, dał do kościoła naszego relikwiarz dziewiętnastu Ojców Świętych papieżów w srebro oprawny.

[1740]

Roku Pańskiego 1740

Sprawiła i oddała kościołowi naszemu Dobrodzika Jejmość Panna ksieni, Zofia Grothówna ornat biały z dalmatykami bardzo bogatej materii, ze wszystkiemi potrzebami, do tego aparatu należącemi, galon srebrny.

[1741]

Roku Pańskiego 1741

dnia 1 stycznia

Oddał Wielmożny Jegomość, ksiądz Dominik Lochman, Dobrodziej nasz do kościoła naszego Partykułę z kolumny Chrystusowej oprawną w srebro, pozłocistą drogiemi kamieniami wkoło szkła przyozdobioną w formę kolumny zrobioną i swoim sumptem sprawioną.

Tegoż roku, dnia 10 lipca sprawiła siostra Teresa Wietrzyńska ${ }^{51}$ antependium adamaszkowe, białe $\mathrm{z}$ galonami złotemi i takowąż frędzlą i oddała kościołowi naszemu do ołtarza Wielkiego. Obrus także z koronami nowy do tegoż ołtarza należący.

Oddał do kościoła naszego Wielmożny Jegomość Pan Mateusz z Przyłęka Groth, łowczy sandomierski dobrodziej, portiery dwie, na szajej ${ }^{52}$ białej kwiatkami kitajkowemi wysadzone, frędzla jedwabna u nich.

Roku 1741 dnia 26 listopada

Oddała dobrodziejka Panna ksieni wanienek miedzianych do pięciu ołtarzów nr 5.

[s. 19]

Roku Pańskiego 1741 dnia 29 września

Oddała Jejmość dobrodziejka Panna ksieni dalmatyki i kapę lamową, błękitną z potrzebami szychowemi, płótnem podszytą, na które aparaty dała suknie Wielmożna Jejmość Pani Antonia Komecka, burgrabina krakowska. Item oddała Dobrodziejka Panna ksieni ornat z bogatej materii biały, potrzeby marcypanowe srebrne, kitajką złotą podszyty, która materię zyskała po nieboszczce dobrodziejce Pannie ksieni.

Item ornat biały morowy, lamowy, potrzeby szychowe, płótnem ceglastym podszyty, która materia została po siostrze Postupalskiej ś.p.

${ }^{51}$ Teresa Wietrzyńska, habit przyjęła 29 VIII 1717 r., śluby wieczyste złożyła 22 U 1719 r., zmarła dnia 10 I 1765. zob. Księga Profesji, s. 35-36.

${ }^{52}$ Saja, szaja, szaia - 1. Poczatkowo wełniana, potem półwełniana tkanina z gorszej przędzy o osnowie lnianej lub bawełnianej, podczas wykańczania poddana gotowaniu w naprężeniu, farbowana i kalandrowana dla połysku. 2. Lekka, gładka lub wzorzysta tkanina półjedwabna (z dodatkiem wełny lub bawełny) o splocie skosnym. 
Dnia 23 grudnia roku 1741

Oddała kościołowi naszemu, siostra Teresa Miroszewska ${ }^{53}$, ornat biały, z bukietami jedwabnemi i złotemi. Potrzeby u niego złote, basztem ${ }^{54}$ białym podszyty, który swoim kosztem sprawiła za złotych 300 .

Item, tegoż dnia grudnia r(oku) 1741, dał Jegomość Pan Mikołaj Grozmaier do zasłaniania monstrancji materię złotą, atłasową, po której bukiety jedwabne do tego dała dobrodziejka Panna ksieni, koronkę srebrną.

\section{[1742]}

Roku 1742 dnia 23 kwietnia

Oddała dobrodziejka Panna ksieni ornat na tercyneli ${ }^{55}$ biały, bukiety szyte, na który ornat dała J.W. JMC. Pani Salomea Ponińska, wojewodzina poznańska, suknię córki swojej. Potrzeby żółte kaimką białą podszyty, które potrzeby i podszycia Dobrodziejka Panna Ksieni dała.

słowa kluczowe: siostry norbertanki, Imbramowice, ksieni, klasztor, Zofia Grotówna

${ }^{53}$ Teresa Miroszewska, habit przyjęła dnia 25 listopada 1725 r. z rąk swego stryja księdza Antoniego Miroszewskiego, on też uczestniczył podczas profesji dnia 30 III 1727 r. Zob. Księga Profesji, s. 38 .

${ }^{54}$ Baszt - lniana lub konopna tkanina, często barwiona na różne kolory. Używana w Polsce w XVIII w. na podszewki i zapewne tańsza odzież.

${ }^{55}$ Tercanela, tercynela, terzanell, tercynella - połyskliwa i ziarnista tkanina jedwabna lub półjedwabna o splocie płóciennym czasem z wzorem kwiatowym uzyskanym broszowaniem. Wyrabiana w XVII i 1 poł. XVIII w. we Włoszech i prawdopodobnie we Francji. Importowana do Polski, używana na suknie, kontusze, żupany. 


\title{
THE LIST OF THINGS DONATED TO THE NORBERTINE SISTERS CHURCH AND CONVENT IN IMBRAMOWICE IN THE YEARS 1712-1742
}

\begin{abstract}
Summary
In the Archives of the Norbertine Sisters in Imbramowice, among many important documents, there is the "The register of the things donated to the church after it had burnt down written on 1 August in 1712." It was probably drawn up at the behest of abbess Zofia Grothówna, who managed the convent for almost forty years. Appointed to this function on 4 August 1703, she held office until her death, which occurred on 31 May 1741. The first notes about the donated things appeared in the registry on 1 August 1712, and it was almost entirely supplemented during the life of Zofia Grothówna. Only one, the last note was entered on 23 April 1742, during the reign of abbess Katarzyna Bąkowska and it concerns a chasuble given to the convent by her.

There were a number of donors who supported the convent in Imbramowice in those difficult times. Among the donors there were both clergy and laymen. Abbess Zofia Grothówna was the one who gave the most things. In addition, Rev. Dominik Lochman donated a great number of valuable things. The information on donations are written in a very explicit way in the registry, which includes the information on the items handed over to the convent as well as the identity of individual donors. The registry information is arranged according to the time of its transfer to the convent. The objects listed in the registry are accompanied by a brief description, including the material which they were made of and the names of the donors.
\end{abstract}

Keywords: Norbertine Sisters, Imbramowice, abbess, convent, Zofia Grothówna 